\title{
Pengaruh Gaya Kepemimpinan Dan Disiplin Kerja \\ Terhadap Kinerja Pegawai Badan Pemberdayaan Perempuan Dan Keluarga Berencana Kota Medan
}

\author{
Hilma Harmen \\ Dwitha Asri Mardani Siregar \\ Fakultas Ekonomi Universitas Negeri Medan \\ Email: hilmaharmen@gmail.com
}

\begin{abstract}
ABSTRAK
Penelitian ini bertujuan untuk mengetahui pengaruh Gaya Kepemimpinan dan Disiplin Kerja terhadap Kinerja Pegawai Badan Pemberdayaan Perempuan dan Keluarga Berencana Kota Medan. Populasi dalam penelitian ini adalah seluruh pegawai Pegawai Badan Pemberdayaan Perempuan dan Keluarga Berencana Kota Medan. Penarikan sampel dalam penelitian ini dengan menggunakan teknik stratified sampling, sampel adalah 64 Pegawai. Data yang digunakan dalam penelitian ini adalah data primer. Data primer diperoleh dari hasil wawancara dan penyebaran angket/ kuesioner. Analisis menggunakan regresi linear berganda dengan rumus $\mathrm{Y}=\mathrm{a}+\mathrm{b}_{1} \mathrm{X}_{1}+\mathrm{b}_{2} \mathrm{X}_{2}$ dan diolah menggunakan program SPSS 16.0 for windows . Dari hasil analisis data diperoleh persamaan regresi berganda yaitu: $Y=5,965+0,656 X_{1}+0,276 X_{2}$. Uji t pada taraf signifikansi $\alpha=0,05$, nilai $t_{\text {hitung }} \mathrm{X}_{1}=4,497$ dan $\mathrm{t}_{\text {tabel }}=1,677$. Maka $\mathrm{t}_{\text {hitung }}>\mathrm{t}_{\text {tabel }}$. Dengan demikian hipotesis yang menyatakan ada pengaruh yang positif dan signifikan antara variabel gaya kepemimpinan dan kinerja Pegawai Badan Pemberdayaan Perempuan dan Keluarga Berencana Kota Medan. Sementara itu nilai $t_{\text {hitung }} X_{2}=2,247$. Maka $t_{\text {hitung }}>t_{\text {tabel }}$. Dengan demikian hipotesis yang menyatakan ada pengaruh yang positif dan signifikan antara variabel disiplin kerja terhadap kinerja Pegawai Badan Pemberdayaan Perempuan dan Keluarga Berencana Kota Medan. Dari hasil uji F diperoleh $F_{\text {hitung }}$ sebesar 14,377 > 3,15 dan taraf signifikansi sebesar $0,000<0,05$. Dengan demikian dapat ditarik kesimpulan bahwa ada pengaruh yang positif dan signifikan antara variabel Gaya Kepemimpinan dan Disiplin Kerja terhadap Kinerja Pegawai Badan Pemberdayaan Perempuan dan Keluarga Berencana Kota Medan.
\end{abstract}

Kata Kunci : Gaya Kepemimpinan, Disiplin Kerja, Kinerja Pegawai.

\begin{abstract}
This study aimed to determine the effect of Leadership Styles and Work Discipline of Employee Performance on Badan Pemberdayaan Perempuan dan Keluarga Berencana Kota Medan. The population in this study were all employees of Badan Pemberdayaan Perempuan dan Keluarga Berencana Kota Medan. Sampling in this study using a stratified sampling, the sample is 64 Employees. The data used in this study is primary data. The Primary data obtained from interviews and questionnaire. Analysis using multiple linear regression formula $Y=a+b 1 x 1+b 2 X 2$ and processed using SPSS 16.0 for Windows. From the analysis of data obtained by multiple regression equation is: $Y=$ $5,965+0,6560,276 X 1+X 2$. T test at significance level $\alpha=0.05$, tcount X1 $=4,497$ and table $=1.677$. So tcount $>$ ttable. Thus the hypothesis that there is a positive and significant influence between the variables of leadership style and performance
\end{abstract}




\section{LIABILITIES (JURNALPENDIDIKAN AKUNTANSI) \\ e-ISSN 2620-5866 (Online) \\ http://jurnal.umsu.ac.id/index.php/LAB \\ Vol. 3 No. 3 Desember 2020 Halaman 168-185 \\ Doi: $10.30596 /$ liabilities.v3i3.5816}

Employees of Badan Pemberdayaan Perempuan dan Keluarga Berencana Kota Medan. Meanwhile tcount X2 = 2.247. So tcount> ttable. Thus the hypothesis that there is a positive and significant influence between the variables on the performance of employee and work discipline of Badan Pemberdayaan Perempuan dan Keluarga Berencana Kota Medan. From the test results obtained F test namely Fcount 14.377> 3.15 and a significance level of $0.000<0.05$. Thus it can be concluded that there is a positive and significant influence between variables Leadership Style and Work Discipline on Employee Performance of Badan Pemberdayaan Perempuan dan Keluarga Berencana Kota Medan.

Keywords : Leadership Style, Work Discipline, Employee Performance.

\section{PENDAHULUAN}

Sumber daya manusia adalah salah satu tonggak penting dalam suatu perusahaan maupun suatu instansi. Mereka berperan sebagai pemikir, perencana, dan pengendali aktivitas dalam suatu instansi tersebut. Agar suatu instansi dapat berjalan baik maka instansi tersebut harus memiliki pegawai yang memiliki pengetahuan dan mampu menjalankan tugas dengan baik demi kelangsungan dan tujuan instansi tersebut. Pada lingkungan instansi, pegawai yang berkualitas adalah pegawai yang melaksanakan pekerjaannya dan mampu memberikan hasil kerja yang baik atau mempunyai prestasi kerja yang tinggi yang dibutuhkan oleh instansi untuk mencapai tujuan.Tingginya hasil kerja pegawai akan berdampak kepada tingginya kinerja instansi (Ardansyah;2014). Kinerja yang dihasilkan oleh pegawai bukanlah suatu kebetulan saja, tetapi banyak faktor yang mempengaruhi di antaranya adalahgaya kepemimpinan dan disiplin yang ditegakkan. Kinerja adalah suatu yang dicapai atau prestasi yang diperlihatkan (Kamus Besar Bahasa Indonesia: 253). Kinerja dalam suatu instansi ditentukan oleh pegawai instansi itu sendiri. Dengan kata lain kinerja merupakan hasil kerja yang dicapai oleh pegawai dalam melaksanakan tugas sesuai dengan tanggung jawab yang diberikan kepadanya. Menurut Mangkunegara (2007:67) Kinerja adalah" hasil kerja secara kualitas dan kuantitas yang dicapai oleh seorang pegawai dalam melaksanakan tugasnya sesuai tanggung jawab yang diberikan kepadanya”. Dengan kata 


\section{LIABILITIES (JURNALPENDIDIKAN AKUNTANSI) \\ e-ISSN 2620-5866 (Online) \\ http://jurnal.umsu.ac.id/index.php/LAB \\ Vol. 3 No. 3 Desember 2020 Halaman 168-185 \\ Doi: $10.30596 /$ liabilities.v3i3.5816}

lain kinerja merupakan hasil kerja yang dicapai oleh pegawai dalam melaksanakan tugas sesuai dengan tanggung jawab yang diberikan kepadanya. Sementara itu, disiplin kerja merupakan sifat atau tingkah laku yang menunjukkan kepatuhan terhadap peraturan dan norma-norma yang berlaku dalam suatu instansi ataupun perusahaan yang berguna untuk meningkatkan keteguhan karyawan dalam mencapai tujuan dalam instansi atau perusahaan tersebut. Kinerja yang baik dapat dipengaruhi oleh disiplin pegawainya (Iriani : 2010) Setiap pemimpin mempunyai gaya kepemimpinan yang berbeda antara yang satu dan yang lain, biasanya gaya kepemimpinan masing-masing pemimpin memiliki kekurangan dan kelebihannya masing-masing yang akan membedakan antara kepemimpinan yang satu dengan yang lain. Selain itu, gaya kepemimpinan yang sesuai akan dapat meningkatkan kinerja dari pegawai sehingga yang menjadi tujuan dari instansi atau perusahaan akan dapat tercapai.

\section{Gaya Kepemimpinan}

Setiap pemimpin akan melakukan yang terbaik untuk instansi yang ia pimpin. Seperti yang telah disebutkan sebelumnya, salah satu indikator keberhasilan suau instansi adalah gaya kepemimpinan yang dianut oleh pemimpinnya sendiri. Terry (2005:192) menyebutkan "Gaya Kepemimpinan adalah kemampuan seseorang atau pemimpin, untuk mempengaruhi perilaku orang lain menurut keinginan -keinginannya dalam suatu keadaan tertentu". Thoha (2010: 49 ) " Gaya kepemimpinan adalah norma perilaku yang digunakan oleh seorang pada saat orang tersebut mencoba mempengaruhi perilaku orang lain,dalam hal ini usaha menyelaraskan persepsi diantara orang yang akan mempengaruhi perilaku dengan orang yang perilakunya akan dipengaruhi menjadi amat penting kedudukannya". Berdasarkan beberapa pendapat yang telah dikemukakan, Menurut Robbins (2006: 460) indikator yang dapat dilihat adalah sebagai berikut :

1. Tidak memberikan kontrol dan koreksi terhadap anggotaanggota Kelompok. 


\section{LIABILITIES (JURNALPENDIDIKAN AKUNTANSI) \\ e-ISSN 2620-5866 (Online) \\ http://jurnal.umsu.ac.id/index.php/LAB \\ vol. 3 No. 3 Desember 2020 Halaman 168-185 \\ Doi: $10.30596 /$ liabilities.v3i3.5816}

2. Keleluasaan dan tanggung jawab yang simpang siur.

3. ketidakmerataan posisi para anggotanya dalam melaksanakan tugasnya.

4. Kebijaksanaan (policity) suatu institusi berada ditangan anggota.

\section{Disiplin Kerja}

Disiplin kerja dalam suatu organisasi bertujuan untuk menghapus sikap dan perilaku yang tidak seharusnya ada dalam organisasi ataupun instansi. Dengan kedisiplinan kerja, maka pegawai tidak akan melakukan tindakan yang dapat merugikan instansi. Menurut Ardana, dkk (2011:134), disiplin kerja merupakan suatu sikap menghormati, menghargai, patuh, dan taat terhadap peraturan-peraturan yang berlaku, baik yang tertulis maupun yang tidak tertulis serta sanggup menjalankannya dan tidak mengelak untuk menerima sanksi-sanksinya. Iriani (2010), menambahkan bahwa kedisiplinan karyawan mutlak diperlukan agar seluruh aktivitas yang sedang dan akan dilaksanakan berjalan sesuai mekanisme yang telah ditentukan..
Menurut Agustini

(2011:63) menyatakan bahwa disiplin mempunyai 3 (tiga) macam bentuk, yaitu :

1. Disiplin Preventif

Disiplin preventif adalah tindakan yang bertujuan untuk mencegah karyawan yang berperilaku tidak sesuai dengan peraturan. Tindakan tersebut mendorong karyawan untuk taat pada berbagai ketentuan yang berlaku dan memenuhi standar yang telah ditetapkan. Tujuan pokoknya adalah untuk mendorong karyawan agar memiliki disiplin pribadi yang tinggi dan agar peran pemimpin tidak terlalu berat dengan pengawasan .

2. Disiplin Korektif

Disiplin korektif adalah tindakan yang bertujuan agar karyawan tidak melakukan pelanggaran yang sudah dilakukan. Tindakan itu biasanya berupa hukuman tertentu yang biasa disebut sebagai tindakan disipliner, antara lain berupa peringatan 


\section{LIABILITIES (JURNALPENDIDIKAN AKUNTANSI) \\ e-ISSN 2620-5866 (Online) \\ http://jurnal.umsu.ac.id/index.php/LAB \\ Vol. 3 No. 3 Desember 2020 Halaman 168-185 \\ Doi: $10.30596 /$ liabilities.v3i3.5816}

lisan dan tulisan, skors, pemecatan.

3. Disiplin Progresif

Disiplin progresif adalah tindakan yang bertujuan memberikan kesempatan kepada karyawan untuk mengambil tindakan korektif sebelum hukuman-hukuman yang lebih serius dilaksanakan tetapi juga memungkinkan manajemen untuk memperbaiki kesalahan memberikan hukumanhukuman yang lebih berat terhadap pelanggaran yang berulang.

Dalam setiap instansi, pemimpin pasti mengharapkan jenis disiplin yang ada pada point pertama, dimana selain disiplin tersebut timbul dari kesadaran pegawai juga akan meringankan tugas pemimpinnya .

\section{Faktor- faktor Disiplin}

Menurut Sutrisno (2009: 94) faktor yang mempengaruhi disiplin kerja adalah sebagai berikut:

1. Besar kecilnya pemberian kompensasi,

dapat mempengaruhi tegaknya disiplin.

Para karyawan akan

memepengaruhi segala peraturan yang berlaku, bila ia merasa mendapat jaminan balas jasa yang setimpal dengan jerih payahnya yang telah dikontribusikan bagi perusahaan.

2. Ada tidaknya keteladanan pimpinan dalam perusahaan, Keteladanan pimpinan sangat penting, karena dalam lingkungan perusahaan, semua karyawan akan selalu memperhatikan bagaimana pimpinan dapat menegakkan disiplin dirinya.

3. Ada tidaknya aturan pasti yang yang dapat dijadikan pegangan, hal ini untuk pembinaan disiplin bila tidak ada aturan tertulis yang pasti untuk dapat dijadikan pegangan bersama.

4. Keberanian pimpinan dalam mengambil tindakan, bagi karyawan yang melanggar disiplin, maka perlu ada keberanian pimpinan untuk mengambil tindakan yang sesuai dengan tindakan pelanggaran yang dibuatnya. 


\section{LIABILITIES (JURNALPENDIDIKAN AKUNTANSI) \\ e-ISSN 2620-5866 (Online) \\ http://jurnal.umsu.ac.id/index.php/LAB \\ Vol. 3 No. 3 Desember 2020 Halaman 168-185 \\ Doi: $10.30596 /$ liabilities.v3i3.5816}

5. Ada tidaknya pengawasan pimpinan, pengawasan dilakukan agar para karyawan agar dapat melaksanakan pekerjaan dengan tepat dan sesuai dengan yang telah ditetapkan.

6. Ada tidaknya perhatian kepada para pegawai, karena karyawan tidak hanya puas dengan penerimaan kompensasi yang tinggi, pekerjaan yang menantang, tetapi juga mereka masih membutuhkan perhatian yang besar dari pimpinannya sendiri.

7. Pemenuhan

kebutuhan, ditentukan oleh tingkatan karakteristik pekerjaan, yang memberikan kesempatan pada individu untuk memenuhi kebutuhannya.

8. Keadilan, merupakan fungsi dari seberapa adil individu diperlakukan di tempat kerja. Kepuasan merupakan hasil persepsi orang bahwa perbandingan antara hasil kerja dan inputnya relatif lebih menguntungkan dibandingkan dengan perbandingan antara keluaran dan masukan pekerjaan lainnya.

9. Diciptakan kebiasaan-kebiasaan yang mendukung tegaknya disiplin. Kebiasaan positif diantaranya adalah saling menghormati, memberikan pujian pada karyawan, mengikutsertakan karyawan dalam pertemuan-pertemuan san sebagainya.

\section{Indikator Disiplin Kerja}

Menurut Hasibuan

(2005:194)

menyebutkan banyak faktor yang mempengaruhi tingkat kedisiplinan karyawan suatu organisasi, diantaranya :

1. Tujuan dan kemampuan

Tujuan dan kemampuan ikut mempengaruhi tingkat kedisplinan karyawan. Tujuan yang akan dicapai harus jelas dan ditetapkan secara ideal serta cukup menantang bagi kemampuan karyawan.

2. Teladan pimpinan

Teladan pimpinan sangat berperan dalam menentukan kedisiplinan karyawan, karena pimpinan dijadikan teladan dan panutan oleh para bawahannya. 


\section{LIABILITIES (JURNALPENDIDIKAN AKUNTANSI) \\ e-ISSN 2620-5866 (Online) \\ http://jurnal.umsu.ac.id/index.php/LAB \\ Vol. 3 No. 3 Desember 2020 Halaman 168-185 \\ Doi: $10.30596 /$ liabilities.v3i3.5816}

3. Balas jasa

Balas jasa ikut mempengaruhi

kedisiplinan karyawan, karena

balas jasa akan memberikan

kepuasan dan kecintaan

karyawan terhadap pekerjaannya.

4. Keadilan

Keadilan ikut mendorong terwujudnya kedisiplinan

karyawan, karena ego dan sifat manusia yang selalu merasa dirinya penting dan minta diperlakukan sama dengan manusia lainnya.

5. Waskat

Waskat (pengawasan melekat) adalah tindakan nyata dan paling efektif dalam mewujudkan kedisiplinan karyawan, karena dengan waskat ini berarti atasan harus aktif dan langsung mengawasi perilaku, moral, sikap, gairah kerja dan prestasi kerja bawahannya.

6. Sanksi/hukuman

Sanksi/hukuman memberikan peranan penting dalam memelihara kedisiplinan karyawan. Dengan sanksi/hukuman yang semakin berat karyawan akan semakin takut untuk melanggar peraturanperaturan perusahaan .

7. Ketegasan

Ketegasan pimpinan dalam melakukan tindakan akan mempengaruhi kedisiplinan karyawan perusahaan. Pimpinan harus berani dan tegas bertindak untuk menghukum sikap karyawan yang indisipliner sesuai dengan sangsi hukuman yang telah ditetapkan.

8. Hubungan kemanusiaan

Hubungan kemanusiaan yang harmonis diantara semua karyawan akan ikut menciptakan kedisiplinan yang baik pada suatu perusahaan. Jika tercipta human relationship yang baik dan harmonis, diharapkan akan terwujud lingkungan dan suasana kerja yang nyaman. Sedangkan menurut Davis (dalam Marlina, 2011:21) menyatakan ada beberapa indiktor disiplin yaitu sebagai berikut :

1. Kehadiran, yaitu kegiatan yang menandakan datang atau tidaknya karyawan untuk melakukan aktivitas pekerjaan. 


\section{LIABILITIES (JURNALPENDIDIKAN AKUNTANSI) \\ e-ISSN 2620-5866 (Online) \\ http://jurnal.umsu.ac.id/index.php/LAB \\ vol. 3 No. 3 Desember 2020 Halaman 168-185 \\ Doi: $10.30596 /$ liabilities.v3i3.5816}

2. Tata cara kerja, yaitu aturan atau ketentuan yang harus dipatuhi oleh pemberi pekerja dalam melaksanakan pekerjaan, hubungan kerja, hubungan antar manusia, serta keamanan perusahaan.

3. Ketaatan pada atasan, yaitu patuh atau mengikuti apa yang diberikan pimpinan dalam perusahaan guna mengerjakan pekerjaan dengan baik.

4. Kesadaran bekerja, yaitu sikap seseorang yang secara sukarela menaati peraturan dan sadar akan tanggung jawab, sehingga karyawan akan mengerjakan tugasnya dengan baik bukan dengan paksaan.

5. Tanggung jawab, yaitu kesediaan karyawan

mempertanggungjawabkan

kebijaksanaan pekerja dan hasil kerjanya, sarana dan prasarana yang dipergunakan, serta perilaku kerjanya.

\section{Kinerja Pegawai}

Kinerja merupakan kegiatan yang sangat penting dinilai dalam suatu organisasi maupun instansi, yakni bagaimana ia melakukan segala sesuatu yang berhubungan dengan suatu pekerjaan, jabatan, atau peranan dalam instansi tersebut. Menurut Mangkunegara (2007 : 67) “ Kinerja adalah hasil kerja secara kualitas dan kuantitas yang ingin dicapai oleh seorang pegawai dalam melaksanakan tugasnya sesuai dengan tanggung jawab yang diberikan kepadanya.Sedangkan menurut Hasibuan (2005: 94) menjelaskan bahwa "Kinerja merupakan hasil kerja yang dicapai seseorang dalam melaksanakan tugas-tugas yang dibebankan kepadanya didasarkan atas kecakapan, pengalaman, kesungguhan serta waktu". Sementara itu menurut Sedarmayanti (2007: 260)

" Kinerja adalah hasil kerja yang dapat dicapai seseorang atau sekelompok orang dalam suatu organisasi, sesuai dengan wewenang dan tanggung jawab masing-masing dalam upaya mencapai tujuan organisasi bersangkutan secara legal, tidak melanggar hukum dan sesuai dengan moral maupun etika." Kinerja merupakan gabungan tiga faktor penting, yaitu kemampuan dan minat seorang pekerja, kemampuan dan 


\section{LIABILITIES (JURNALPENDIDIKAN AKUNTANSI) \\ e-ISSN 2620-5866 (Online) \\ http://jurnal.umsu.ac.id/index.php/LAB \\ vol. 3 No. 3 Desember 2020 Halaman 168-185 \\ Doi: $10.30596 /$ liabilities.v3i3.5816}

penerimaan atas penjelasan delegasi tugas ,serta peran dan tingkat motivasi seorang pekerja hal tersebut sesuai dengan pernyataan Hasibuan (2005: 94)". Semakin tinggi ketiga faktor tersebut, maka akan semakin tinggi juga kinerja pegawainya. Menurut Mangkunegara (2007:16) faktor yang mempengaruhi kinerja, yaitu :

1. Faktor individu, secara psikologis, individu yang normal adalah yang memiliki integritas yang tinggi antara fungsi rohani dan jasmani. Maka dengan adanya intergritas tersebut individu memiliki konsentrasi yang baik.

2. Faktor lingkungan organisasi. Faktor lingkungan kerja organisasi sangat menunjang bagi individu dalam mencapai kinerja. Faktor lingkungan organisasi yang dimaksud antara lain uraian jabatan yang jelas, target kerja yang menantang, pola komunikasi yang efektif, hubungan kerja yang harmomis, rekan kerja yang respek dan dinamis, peluang berkarir dan fasilitas kerja yang relatif memadai.

Menurut Sofyandi

(2008:123)

Penilaian kinerja adalah penilaian tentang prestasi kerja karyawan dan akuntabilitasnya. Dalam persaingan global, perusahaan-perusahaan menuntut kinerja yang tinggi. Seiring dengan itu, karyawan membutuhkan umpan balik atas kinerja mereka sebagai pedoman Adapun tujuan dari penilaian kinerja adalah untuk mengukur tinggi rendahnya kompensasi serta administrasi bagi tenaga kerja. Moeheriono (2009:113) menyatakan tujuan penilaian kinerja adalah :

1. Kinerja karyawan bisa dikelola secara efektif dan efisien agar kinerja karyawan selalu meningkat.

2. Terjadi proses komunikasi timbal balik antara penilai dan yang dinilai sehingga dapat mengeliminasi berbagai kemungkinan konflik yang akan timbul.

3. Terjadi serangkaian proses perencanaan, pembimbingan, pendokumentasian, dan review kinerja terintegrasi. 


\section{LIABILITIES (JURNALPENDIDIKAN AKUNTANSI) \\ e-ISSN 2620-5866 (Online) \\ http://jurnal.umsu.ac.id/index.php/LAB \\ Vol. 3 No. 3 Desember 2020 Halaman 168-185 \\ Doi: $10.30596 /$ liabilities.v3i3.5816}

4. Mendorong motivasi dan meningkatkan

komitmen karyawan untuk lebih maju.

5. Menciptakan transparansi dan keadilan dalam penilaian.

6. Timbulnya input dalam perencanaan penggantian jabatan.

7. Memberikan masukan kepada perusahaan perihal kinerja seluruh karyawan sebagai dasar untuk menentukan strategi perusahaan.

1. Kualitas. Kualitas kerja diukur dari persepsi pegawai terhadap kualitas pekerjaan yang dihasilkan serta kesempurnaan tugas terhadap keterampilan dan kemampuan pegawai.

2. Kuantitas. Merupakan jumlah yang dihasilkan dinyatakan dalam istilah seperti jumlah unit, jumlah siklus aktivitas yang diselesaikan.

3. Ketepatan waktu. Merupakan tingkat aktivitas diselesaikan pada awal waktu yang dinyatakan, dilihat dari sudut koordinasi dengan hasil output serta memaksimalkan waktu yang tersedia untuk aktivitas lain.
4. Efektivitas. Merupakan tingkat penggunaan sumber daya organisasi (tenaga, uang, teknologi, bahan baku) dimaksimalkan dengan maksud menaikkan hasil dari setiap unit dalam penggunaan sumber daya.

5. Kemandirian. Merupakan tingkat seorang pegawai yang nantinya akan dapat menjalankan fungsi kerjanya Komitmen kerja.

\section{METODOLOGI PENELITIAN}

Penelitian ini dilakukan di Badan Pemberdayaan Perempuan dan Keluarga Berencana Kota Medan Jalan Ibus Raya No.131 A Medan. Populasi adalah Pegawai pada Badan Pemberdayaan Perempuan dan Keluarga Berencana Kota Medan berjumlah 177 orang pegawai. Dengan demikian jumlah populasi dalam penelitian ini adalah 177 orang pegawai. Tehnik pengambilan sampel yang digunakan berdasarkan pada rumus Slovin sebagai patokan untuk menentukan sampel minimal yang harus diambil. Jadi, sampel yang diambil adalah 64 orang. Teknik pengambilan sampel menggunakan 


\section{LIABILITIES (JURNALPENDIDIKAN AKUNTANSI) \\ e-ISSN 2620-5866 (Online) \\ http://jurnal.umsu.ac.id/index.php/LAB \\ Vol. 3 No. 3 Desember 2020 Halaman 168-185 \\ Doi: 10.30596/liabilities.v3i3.5816}

metode stratified sampling

Untuk memperoleh data yang diperlukan, penulis menggunakan alat pengumpulan data melalui : Observasi, Studi kepustakaan, Wawancara dan penyebaran Angket / Kuesioner. Teknik analisis data menggunakan uji asumsi klasik, analisis regresi berganda dan uji hipotesis.

\section{HASIL DAN PEMBAHASAN}

Berdasarkan hasil Uji normalitas dengan menggunakan Uji Kolmogrov-Smirnov test (KS) diperoleh nilai Kolmogrov-Smirnov Z sebesar 1,270 untuk variabel Kinerja $(\mathrm{Y}), \quad 0,881 \quad$ untuk Gaya Kepemimpinan $\left(\mathrm{X}_{1}\right)$ dan 1,009 untuk variabel Disiplin Kerja $\left(\mathrm{X}_{2}\right)$. Nilai Kolmogrov-Smirnov $\quad \mathrm{Z}$ yang diperoleh <1,97 dan nilai Asymp.Sig (2-tailed)> 0,05 sehingga dengan demikian dapat disimpulkan bahwa seluruh data dalam penelitian ini terdistribusi normal. Berdasarkan hasil uji normalitas tersebut dapat diketahui bahwa level signifikan dari masing-masing variabel adalah 0,079 Kinerja ; 0,420 Gaya Kepemimpinan dan 0,261 untuk variabel Disiplin Kerja .Sehingga dapat disimpulkan bahwa ketiga variabel dalam penelitian ini adalah berdistribusi normal karena memilki nilai signifikansi lebih besar dari 0,05 dimana dalam hal ini 0,079:0,420:0,261 > 0,05. Untuk mendeteksi apakah model regresi yang dipakai bebas dari permasalahan multikolinearitas dapat dilihat dari besar VIF (Variance Inflation Factor) dan toleransi tidak kurang dari 0,1 . Hingga uji multikolinearitas pada penelitian ini dapat dilihat bahwa tidak adanya masalah Multikolinearitas. Dimana nilai toleransi variabel Gaya Kepemimpinan $\left(\mathrm{X}_{1}\right)$ dan Disiplin Kerja $\left(\mathrm{X}_{2}\right)$ masing-masing sebesar 0,979 dan nilai VIF 1,021. Dengan kata lain nilai tolerance $0,979<10$. Berdasatkan hasil uji regresi liner berganda dapat dilihat nilai konstansta (nilai a) sebesar 5,965 dan untuk gaya kepemimpinan (nilai b) sebesar 0,656 serta untuk disiplin kerja (nilai c) sebesar 0,276. Sehingga dapat diperoleh persamaan regresinya sebagai berikut

$Y=5,965+0,656 X_{1}+0,276 X_{2}+e$ 


\section{LIABILITIES (JURNALPENDIDIKAN AKUNTANSI) \\ e-ISSN 2620-5866 (Online) \\ http://jurnal.umsu.ac.id/index.php/LAB \\ vol. 3 No. 3 Desember 2020 Halaman 168-185 \\ Doi: $10.30596 /$ liabilities.v3i3.5816}

Yang berarti :

1. Konstanta sebesar 5,965 dapat diartikan bahwa jika tidak ada variabel gaya kepemimpinan dan variabel disiplin kerja maka nilai kinerja pegawai adalah sebesar 5,965 .

2. Koefisien X1 sebesar 0,656 menyatakan bahwa kenaikan satu satuan gaya kepemimpinan akan meningkatkan kinerja pegawai sebesar 0,656.

3. Koefisien regresi X2 sebesar 0,276 menyatakan bahwa bahwa kenaikan satu satuan disiplin kerja akan meningkatkan kinerja pegawai sebesar 0,276

Berdasarkan hasil uji hipotesis dengan menggunakan uji $\mathrm{F}$ dapat disimpulkan jika $F_{\text {hitung }}>F_{\text {tabel }}$ maka hipotesis diterima dan jika $F_{\text {hitung }}<$ $F_{\text {tabel }}$ maka hipotesis ditolak. $F_{\text {tabel }}$ dilihat dari tabel distribusi $\mathrm{F}$ dengan ketentuan yaitu taraf signifikansi 95 $\%$ dan alpha $5 \%$ serta derajat kebebasan (dk) dengan ketentuan n-3 $=64-3=61$. Dengan ketentuan tersebut diperoleh angka $F_{\text {tabel }}$ sebesar 3,15 diperoleh $\mathrm{F}_{\text {hitung }}$ sebesar 14,377 lebih besar dari $F_{\text {tabel }}$ sebesar 3,15 dan taraf signifikansi sebesar $0,000<$
0,05.Sehingga dapat disimpulkan bahwa secara simultan variabel bebas gaya kepemimpinan dan disiplin kerja berpengaruh positif dan signifikan terhadap variabel terikat kinerja.

Uji t dilakukan untuk mengetahui gaya kepemimpinan dan disiplin kerja terhadap kinerja pegawai secara parsial (individu). Pengaruh dapat dilihat dari nilai $t_{\text {hitung }}$, jika nilai thitung $>t_{\text {tabel }}$ maka ada pengaruh secara parsial variabel gaya kepemimpinan dan disiplin kerja terhadap kinerja pegawai. Dalam penelitian ini, $t_{\text {tabel }}$ dilihat dari tabel 4.22 distribusi $\mathrm{t}$ dengan ketentuan taraf signifikansi 95 $\%$ dan alpha $5 \%$ serta derajat kebebasan (dk) dengan ketentuan n-3 $=64-3=61$. Dengan ketentuan tersebut diperoleh angka $t_{\text {tabel }}$ sebesar 1,670. Berdasarkan tabel diperoleh hasil sebagai berikut :

1. Variabel gaya kepemimpinan memiliki $t_{\text {hitung }}>t_{\text {tabel, }}$ yaitu sebesar 4,497>1,670 dan taraf signifikansi sebesar $0,000<0,05$ sehingga dapat disimpulkan bahwa variabel gaya kepemimpinan berpengaruh 


\section{LIABILITIES (JURNALPENDIDIKAN AKUNTANSI) \\ e-ISSN 2620-5866 (Online) \\ http://jurnal.umsu.ac.id/index.php/LAB \\ Vol. 3 No. 3 Desember 2020 Halaman 168-185 \\ Doi: $10.30596 /$ liabilities.v3i3.5816}

positif dan signifikan secara parsial terhadap kinerja pegawai.

2. Variabel disiplin kerja memiliki $t_{\text {hitung }}>\mathrm{t}_{\text {tabel, }}$ yaitu sebesar 2,247> 1,670 dan taraf signifikansi sebesar $0,028<0,05$ sehingga dapat disimpulkan bahwa variabel disiplin kerja berpengaruh positif dan signifikan secara parsial terhadap kinerja pegawai.

Uji Koefisien Determinasi adalah untuk mengetahui besarnya pengaruh semua variabel independen terhadap variabel dependen. Hasil uji koefisien determinasi $\left(\mathrm{R}_{2}\right)$ ditunjukkan dengan angka R Square Berdasarkan tabel 4.23 diperoleh nilai koefisien determinasi R Square sebesar 0,320. Nilai R Square menunjukkan bahwa variabel independen yaitu variabel gaya kepemimpinan dan disiplin kerja mampu menjelaskan variabel dependen yaitu kinerja sebesar 0,320 $(32,0 \%)$ dan sisanya sebesar $68,0 \%$ dipengaruhi oleh faktor - faktor lain yang tidak dibahas dalam penelitian ini.

Dalam penelitian ini diperoleh data dengan menyebar kuesioner dan wawancara kepada resonden yaitu pegawai Badan Pemberdayaan Perempuan dan Keluarga Berencana Kota Medan . Penelitian ini bertujuan untuk mengetahui pengaruh Gaya Kepemimpinan dan Disiplin Kerja terhadap Kinerja Pegawai. Gaya kepemimpinan merupakan kemampuan pemimpin dalam berperilaku, sifat dan sikap pemimpin yang digunakan untuk mempengaruhi bawahannya agar mau bekerja sesuai keinginannya guna mencapai tujuan organisasi. Gaya kepemimpinan ini sendiri dimaksudkan agar dapat menciptakan keadaan yang efektif dan efisien serta kondusif sehingga secara tidak langsung akan meningkakan kinerja pegawai dan mencapai tujuan organisasi dengan sendirinya. Demikian juga halnya dengan disiplin pegawai merupakan suatu sikap, tingkah laku, dan perbuatan yang sesuai dengan peraturan baik tertulis maupun tidak tertulis, dan bila melanggar akan mendapat sanksi. Dalam suatu instansi pelaksanaan gaya kepemimpinan yang benar akan berdampak positif terhadap tercapainya efektifitas dan efisiensi kerja yang berarti kinerja pegawai 


\section{LIABILITIES (JURNALPENDIDIKAN AKUNTANSI) \\ e-ISSN 2620-5866 (Online) \\ http://jurnal.umsu.ac.id/index.php/LAB \\ Vol. 3 No. 3 Desember 2020 Halaman 168-185 \\ Doi: $10.30596 /$ liabilities.v3i3.5816}

akan tercapai. Sedangkan disiplin kerja berkaitan dengan tingkah laku pegawai yang akan dinilai. Oleh karena itu terlihat jelas pengaruh gaya kepemimpinan dan disiplin kerja terhadap kinerja pegawai. Pernyataan tersebut sesuai dengan hasil penelitian yang didapat peneliti pada Badan Pemberdayaan Perempuan dan Keluarga Berencana Kota Medan. Berdasarkan penelitian yang dilakukan terhadap 64 pegawai maka diperoleh hasil bahwa :

1. Gaya Kepemimpinan $\left(\mathrm{X}_{1}\right)$ berpengaruh positif dan signifikan terhadap kinerja. Hal ini terlihat dari hasil uji t, yang menunjukkan $t_{\text {hitung }}>t_{\text {tabel, }}$, yaitu sebesar 4,497 > 1,670.

2. Disiplin Kerja $\left(\mathrm{X}_{2}\right)$ berpengaruh positif dan signifikan terhadap kinerja. Hal ini terlihat dari hasil uji t, yang menunjukkan $t_{\text {hitung }}>$ $t_{\text {tabel, }}$ yaitu sebesar 2,247> 1,670 .

Hasil pengujian hipotesis dengan menggunakan uji $t$ tersebut menunjukkan bahwa faktor-faktor gaya kepemimpinan dan disiplin kerja berpengaruh secara signifikan terhadap kinerja pegawai Badan Pemberdayaan Perempuan dan
Keluarga Berencana Kota Medan. Hal ini diperoleh dari jawaban responden melalui kuesioner yang disebarkan kepada respoden. Dapat diinterpretasikan, jika gaya kepemimpinan dan disiplin kerja baik maka kinerja pegawai juga akan semakin meningkat. Berdasarkan hasil analisis varians diperoleh $F_{\text {hitung }}$ sebesar 14,377 dan taraf signifikansi sebesar $0,000<0,05$. Sehingga hasil ini menunjukkan bahwa secara simultan variabel bebas gaya kepemimpinan dan disiplin kerja berpengaruh positif dan signifikan terhadap variabel terikat kinerja. Nilai $\mathrm{R}$ square sebesar 0,320, hal ini menunjukkan bahwa variabel independen yaitu variabel gaya kepemimpinan dan disiplin kerja mampu menjelaskan variabel dependen yaitu kinerja sebesar 0,320 $(32,0 \%)$ dan sisanya sebesar $68,0 \%$ dipengaruhi oleh faktor-faktor lain yang tidak dibahas dalam penelitian ini.

\section{KESIMPULAN DAN SARAN}

\section{Kesimpulan}

1. Kinerja sebesar 5,965 menyatakan bahwa jika variabel 


\section{LIABILITIES (JURNALPENDIDIKAN AKUNTANSI) \\ e-ISSN 2620-5866 (Online) \\ http://jurnal.umsu.ac.id/index.php/LAB \\ Vol. 3 No. 3 Desember 2020 Halaman 168-185 \\ Doi: $10.30596 /$ liabilities.v3i3.5816}

Gaya Kepemimpinan dan

Disiplin Kerja tidak berubah (konstan) maka Kinerja pegawai akan tetap sebesar 5,965. Pengaruh Gaya Kepemimpinan sebesar 0,656 menyatakan setiap terjadi peningkatan gaya kepemimpinan 1 kali maka akan meningkatkan kinerja sebesar 0,656 dengan asumsi variabel lain dianggap tetap. Demikian halnya dengan Disiplin Kerja sebesar 0,276 menyatakan setiap terjadi peningkatan Disiplin Kerja 1 kali maka akan meningkatkan kinerja sebesar 0,276 dengan asumsi variabel lain dianggap tetap.

2. Hasil Uji Hipotesis pada penelitian in menyatakan bahwa Gaya Kepemimpinan $(4,497)$ Disiplin kerja $(2,247)>1,677$ atau $t_{\text {hitung }}>t_{\text {tabel }}$ maka hipotesis diterima yang artinya bahwa Gaya Kepemimpinan dan Disiplin kerja berprngaruh positif dan signifikan terhadap Kinerja Pegawai Badan Pemberdayaan Perempuan dan Keluarga Berencana Kota Medan .

3. Hubungan antara Gaya Kepemimpinan dan Disiplin Kerja secara bersama-sama memiliki pengaruh terhadap Kinerja sebesar 0,320 atau 32,0\% yang artinya bahwa secara bersama-sama Gaya Kepemimpinan dan Disiplin Kerja mempunyai pengaruh sebesar $32,0 \%$ dan sisanya sebesar $68,0 \%$ dipengaruhi oleh faktor - faktor lain yang tidak dibahas dalam penelitian ini.

\section{Saran}

1. Dari hasil penelitian dapat dilihat bahwa Gaya Kepemimpinan memberikan pengaruh terhadap Kinerja Pegawai Badan Pemberdayaan Perempuan dan Keluarga Berencana Kota Medan. Oleh karena itu hendaknya pemimpin harus memberikan perhatian khusus pada para pegawai dan lebih bertanggung jawab terhadap pekerjaan dan jabatan yang diembannya. Keberhasilan kinerja pegawai adalah salah satu unsur dalam meningkatkan kinerja organisasi. Diharapkan dengan tercapainya gaya kepemimpinan yang baik maka kinerja pegawai Badan Pemberdayaan Perempuan dan Keluarga Berencana Kota Medan pun akan semakin baik. Dalam hal ini, sebaiknya gaya kepemimpinan yang digunakana adalah gaya kepemimpinan demokratis ataupun transformasional.

2. Disiplin Kerja dari para pegawai harus lebih ditingkatkan lagi. Pegawai harus lebih menghormati pemimpin dengan datang tepat waktu, dan menyelesaikan tugas tepat waktu agar tidak ada lagi surat teguran yang didapat oleh instansi. 


\section{LIABILITIES (JURNALPENDIDIKAN AKUNTANSI) \\ e-ISSN 2620-5866 (Online) \\ http://jurnal.umsu.ac.id/index.php/LAB \\ Vol. 3 No. 3 Desember 2020 Halaman 168-185 \\ Doi: $10.30596 /$ liabilities.v3i3.5816}

3. Mengingat penelitian ini dipengaruhi oleh beberapa faktor diluar variabel penelitian, maka Badan Pemberdayaan Perempuan dan Keluarga Berencana Kota Medan perlu memperhatikan aspek lingkungan kerja baik fisik maupun non fisik, motivasi, komunikasi ,dll sehingga pegawai menghasilkan kinerja yang optimal.

4. Penelitian ini masih bersifat umum, karena terlihat masih banyak faktor lain yang mempengaruhi kinerja pegawai Badan Pemberdayaan Perempuan dan Keluarga Berencana Kota Medan, maka penulis menyarankan bagi peneliti selanjutnya untuk menggunakan variabel dalan penelitian ini untuk diteliti di masa yang akan datang.

\section{DAFTAR PUSTAKA}

Agustin.Maria.2012.Pengaruh Gaya Kepemimpinan,Pengembang an Sumber Daya Manusia dan Disiplin Kerja terhadap Kinerja Pegawai Sekertariat Dewan Perwakilan Daerah Provinsi Sulawesi Tengah.EJurnal.

Katalogis.ISSN:23022019.Vo:1.No:1.Hal:95-103 .

Agustini.Fauzia.2011. Manajemen Sumber Daya Manusia Lanjutan. Medan: Medanatera.
Agustuti.Handayani.2010.Analisis

Gaya Kepemimpinan dan Motivasi Kerja Terhadap Kinerja Pegawai Pada Dinas Tenaga Kerja Kota Lampung. Jurnal Ilmiah Administrasi Publik dan Pembangunan, ISSN : 20870825

Vol;1.No;1.Hal;84-92

Ardana, I Komang, Ni Wayan Mujiati dan I Wayan Mudiartha Utama.2011. Manajemen Sumber Daya Manusia. Edisi Pertama : Graha Ilmu.

Ardansyah, Wasilawati.2014. Pengawasan, Disiplin Kerja,dan Kinerja Pegawai Badan Pusat Statistik Kabupaten Lampung Tengah. Jurnal JMK. ISSN:14111438.Vol:16.No:2.Hal: 153162.

Arikunto, Suharsimi .2005. Prosedur peneitian. Edisi revisi. Yogyakarta: Rineka Cipta.

Penelitian" : Suatu Pendekatan Praktik. Edisi Revisi.Jakarta: Rineka Cipta.

Brahmasari, Ida Ayu. Pengaruh Motivasi Kerja, Kepemimpinan dan Budaya Organisasi Terhadap Kepuasan Kerja Karyawan Serta Dampaknya Pada Kinerja Perusahaan (Studi Kasus Pada PT. Pei Hai Internasional Wiratama Indonesia). Jurnal Manajemen dan Kewirausahaan, Vol: 10 hal 


\section{LIABILITIES (JURNALPENDIDIKAN AKUNTANSI) \\ e-ISSN 2620-5866 (Online) \\ http://jurnal.umsu.ac.id/index.php/LAB \\ Vol. 3 No. 3 Desember 2020 Halaman 168-185 \\ Doi: $10.30596 /$ liabilities.v3i3.5816}

: 2. September 2008: 124135

Dalimunthe, Syahdan Taufiq. 2011. Pengaruh Gaya Kepemimpinan terhadap Prestasi Kerja Karyawan Pada PT.Pertamina Instalasi Medan Group. Skripsi. (http://repository.usu.ac.id/bi tstream/123456789/22559/4/ chapter\%2011.df) diakses oleh Dwitha, 16 Oktober 2014

Davis. 2007. Prilaku dalam Organisasi. Edisi Revisi. CV. Haji Mas Agung: Jakarta

Harlie. M.2011. Pengaruh Disiplin Kerja,Motivasi dan Pengembangan Karier terhadap Kinerja Pegawai Negeri Sipil pada Pemerintah Kabupaten Tabalong di Tanjung Kalimantan Selatan. Jurnal Manajemen Akuntansi. ISSN: 16935241.Vol:11.No:2. Hal:860867

Hasibuan,Malayu S.P.2005 organisasi dan motivasi: dasar peningkatan produktivitas. Cetakan kelima. Jakarta: PT.Bumi Aksara.

Iriani, Nur Ida. 2010. Motivasi Intrinsik, Motivasi Ekstrinsik, dan Disiplin kerja Pengaruhnya Terhadap Kinerja Pegawai pada Kantor Dinas Pendidikan Kabupaten Sambas. Jurnal Aplikasi Manajemen. ISSN.1693-
5241.Vol:8.No:2. Hal 561569

Kartono.Kartini. 2014. Pemimpin dan Kepemimpinan . Jakarta:

PT.Rajagrafindo.

Kuncoro.Mudrajad.2009. Metode Riset untuk Bisnis dan Ekonomi. Edisi 3.Jakarta: Erlangga.

Mangkunegara. Anwar .Prabu.2007. Sumber daya Perusahaan edisi dari teori ke praktik, Bandung:Alfabeta

Moeheriono. 2009. Pengukuran Kinerja Berbasis Kompetensi. Bogor : Ghalia Indonesia.

Oktavianus.Doni.2013.Gaya

Kepemimpinan dan Budaya Organisasi pengaruhnya terhadap Kinerja Pegawai Kantor Kelurahan Malayang I Manado. Jurnal EMBA.ISSN:2303-

1174.Vol:1.No:4.Hal:151159

Riduan dan Kuncoro . 2008. Cara menggunakan dan memakai analisis jalur (path analisis): Bandung. Alfabeta.

Rivai.veithzal dan Basri .2005. Performence Appraisal : Sistem yang Tepat untuk Menilai Kinerja Karyawan dan Meningkatkan Daya Saing Perusahaan. Jakarta : PT. Rajagrafindo Persada.

Robbins , P.Stephen.2006. Perilaku

Organisasi .Jakarta : Indeks. 


\section{LIABILITIES (JURNALPENDIDIKAN AKUNTANSI) \\ e-ISSN 2620-5866 (Online) \\ http://jurnal.umsu.ac.id/index.php/LAB \\ Vol. 3 No. 3 Desember 2020 Halaman 168-185 \\ Doi: 10.30596/liabilities.v3i3.5816}

Salam.Jamhur,dkk.2013. Hubungan

Gaya Kepemimpinan

Terhadap Kinerja Tenaga

Kesehatan di Puskesmas

Wara Selatan Kota Palopo.

Jurnal AKK.Vol:2.No:2.Hal

29-34

Sedarmayanti .2007. Manajemen

Sumber Daya Manusia.

Bandung: Refika Aditama.

Siagian . Sondang P.2007.

Manajemen Sumber Daya

Manusia. Jakarta : Bumi

Aksara

Sofyandi.Herman. 2008. Manajemen

Sumber Daya

Manusia,Yogyakarta ; Graha

Ilmu

Sutrisno.Edy.2009. Manajemen

Sumber Daya Manusia. Edisi

I. Kencana:Jakarta. Prenada

Media Group

Tampubolon, Manahan P. 2004.

Perilaku Keorganisasian,

Edisi pertama. Jakarta:

Ghalia Indonesia

Terry.R.George.2005. Dasar-Dasar

Manajemen. cetakan

kesembilan. Jakarta:

PT.Bumi Aksara.

Thoha.Mifta. 2010. Kepemimpinan

dalam Manajemen. Jakarta :

PT.Rajagrafindo.

Umar, Husein. 2005. Evaluasi Kinerja Perusahaan. Jakarta

: Gramedia Pustaka Utama

Wibowo. 2007. Manajemen Kinerja.

Edisi 1. Jakarta: PT. Raja

Grafindo Persada. 